\title{
MENGHINDARI KRISIS LEGITIMASI: KEBIJAKAN PENDIDIKAN AKUNTANSI DARI PERSPEKTIF KEPERILAKUAN
}

\section{AVOIDING CRISIS OF LEGITIMACY: ACCOUNTING EDUCATION POLICY FROM BEHAVIORAL PERSPECTIVE}

\author{
Oleh: \\ Ertambang Nahartyo
}

Fakultas Ekonomika dan Bisnis Universitas Gadjah Mada

\begin{abstract}
Abstrak
Esai ini memberikan otokritik kepada pendidikan tinggi akuntansi dari perspektif pondasi teori yang digunakan dalam edukasi di bidang akuntansi. Posisi yang saya ajukan merupakan ekstensi dan kontekstualisasi kritik yang disampaikan oleh Ghoshal (2005) dan Cohen dan Holder-Webb (2006). Esai ini mendiskusikan bagaimana pendidikan akuntansi sedang mempertaruhkan legitimasinya dalam mempersiapkan akuntan yang andal dan berintegritas tinggi. Pembahasan diperluas ke masalah krisis ideologi dalam pendidikan akuntansi. Salah satu akar penyebab penurunan relevansi pendidikan akuntansi, yaitu ketergantungan berlebihan terhadap teori ekonomika tradisional, dikupas. Kemudian, esai ini menyampaikan rekomendasi kepada institusi penyelenggara pendidikan akuntansi untuk mengadopsi perspektif keperilakuan yang lebih luas agar nilai ideal pendidikan akuntansi tetap dapat dicapai dan dipertahankan.
\end{abstract}

Kata Kunci: Krisis Legitimasi, Kebijakan Pendidikan Akuntansi, Perspektif Keperilakuan

\begin{abstract}
This essay provides self-criticism to higher education from the perspective of theory used as the foundation of the accounting education. I propose an extension and contextualization of criticism delivered by Ghoshal (2005) and Cohen and Holder-Webb (2006). This essay discusses how accounting education puts its legitimacy at risk. The discussion expands to the crisis of ideology in accounting education. In particular, I analyze one of the root causes of the decline in the relevance of accounting education, an excessive dependence on traditional economics theory. Finally, this essay make recommendations to accounting education providers to adopt a broader perspective of behavioral accounting.
\end{abstract}

Keywords: Crisis of Legitimacy, Accounting Education Policy, Behavioral Perspective 


\section{PENDAHULUAN}

\section{Pendidikan Akuntansi: Legitimasi yang Dipertaruhkan}

Lebih dari satu dasawarsa yang lalu, kekhawatiran tentang keberlanjutan dan relevansi pendidikan akuntansi telah bermula. Albrecht dan Sack (2000), misalnya, telah menyuarakan keprihatinan ini lewat monograf mereka yang monumental. Dengan dukungan sponsor tiga organisasi besar akuntansi di Amerika, Institute of Management Accountants (IMA), American Institute of Certified Public Accountants (AICPA), dan American Accounting Association (AAA), serta lima kantor akuntan publik terbesar di dunia, studi yang dilaksanakan oleh kedua edukator akuntansi di atas menyampaikan pesan bahwa pendidikan akuntansi telah dirundung masalah kronis yang mengancam keberlanjutan profesi akuntansi. Fakta yang mereka ajukan adalah penurunan kuantitas mahasiswa akuntansi yang bermutu, keengganan para akuntan praktisi untuk melanjutkan pendidikan ke jenjang yang lebih tinggi, dan banyaknya keluhan tentang pendidikan akuntansi yang kedaluwarsa dan memerlukan penanganan serius untuk mengembalikan kondisinya.

Sebuah studi yang luar biasa dengan dukungan segenap institusi akuntansi yang luar biasa dengan hasil yang luar biasa pada jaman itu. Apalagi, sejumlah stigma terhadap profesi akuntansi secara umum berlaku saat itu. Anjing penjaga aset korporat, penyedia jasa kleris tata buku yang kaku dalam penerapan aturan, dan pembuat laporan keuangan yang tidak paham konteks sosial merupakan beberapa cap negatif terhadap profesi akuntansi. Simpulan yang diajukan oleh Albrecht dan Sack bisa jadi mengokohkan stigma yang sudah ada. Pendidikan akuntansi, menurut mereka, terlalu berkonsentrasi pada pembentukan tenaga ahli akuntansi yang piawai dengan pekerjaan yang bersifat teknis tanpa pengetahuan yang memadai mengenai lingkungan bisnis. Pendidikan akuntansi dipandang tidak cukup membekali mahasiswa dengan ketrampilan dalam menghadapi kehidupan kompetitif di dunia nyata.

Kedua akuntan pendidik tersebut kemudian merekomendasi langkah-langkah utama untuk merevitalisasi pendidikan akuntansi. Secara garis besar, mereka mengusulkan, selain perubahan pedagogi, perombakan besar kurikulum akuntansi untuk menjamin relevansinya dengan kondisi dunia nyata yang didikte oleh perubahan teknologi, globalisasi, dan peningkatan intensitas kompetisi. Tegasnya, institusi pendidikan akuntansi harus mengadopsi filosofi fokus terhadap pelanggan (customer focus) untuk tetap berada pada kondisi kompetitif di dalam pasar (halaman 65).

Sayang sekali, studi ini kemudian harus berhadapan dengan cobaan yang lebih besar daripada sekadar kekhawatiran: skandal Enron yang juga melibatkan Arthur Andersen, salah satu kantor akuntan besar dunia yang juga bertindak sebagai sponsor penelitian. Fenomena ini memunculkan satu pertanyaan yang menggelisahkan sebagian kita sebagai pelaku pendidikan akuntansi di Indonesia. Sebuah pertanyaan yang sulit dijawab bagi sebagian edukator tetapi amat mudah, sehingga bahkan dapat dikategorikan sebagai pertanyaan retorik, bagi sebagian yang lain:

"Manakah yang berefek lebih besar terhadap dunia pendidikan akuntansi, skandal keuangan yang berskala mega seperti kasus Enron dan sederetan perusahaan besar lain ataukah kekhawatiran tentang penurunan minat terhadap dunia akuntansi? “

Bagi saya, ada hal yang lebih besar daripada irelevansi kurikulum akuntansi dalam menghadapi permintaan pasar. Hubungan antara pendidikan akuntansi dengan praktik akuntansi tidak boleh bersifat resiprokal murni. Pendidikan akuntansi harus dapat memberikan pengaruh besar terhadap dunia praktik. Namun, pengaruh dunia praktik terhadap pendidikan akuntansi harus melewati filter ideologi yang 
bersumber dari filosofi moral yang tepat. Gelombang pengaruh tanpa saringan dari praktik dunia global merupakan benih terjadinya bencana kemanusiaan yang lebih besar di kemudian hari.

\section{Krisis Ideologi dalam Kurikulum Pendidikan Akuntansi}

Sorotan terhadap kelemahan pendidikan bisnis berfokus pada dua titik. Pertama, kritik menunjuk pada ketidakmampuan pendidikan akuntansi dan bisnis dalam membentuk kepribadian dan profesi yang berintegritas (Adler, 2002). Kedua, pendidikan tinggi bisnis dituduh tidak dapat memainkan peran penting dalam mereduksi efek buruk skandal keuangan yang terjadi dengan intensitas yang tinggi (Gioia, 2002).

Alih-alih menghasilkan pribadi lulusan yang dapat menopang upaya menuju kehidupan yang lebih baik, sekolah bisnis ditunjuk sebagai salah satu sumber penyebab krisis multidimensi yang secara cepat menjalar ke beragam domain dan area geografis.

Pendidikan tinggi dicap sebagai wahana upaya besar yang ditujukan untuk tujuan sempit dan dangkal: lapangan pekerjaan. Sekolah adalah toko, mahasiswa menjadi pelanggan atau konsumen, sedangkan para dosen adalah wirausaha penyedia jasa pendidikan praktis yang diarahkan oleh logika dan kebijakan pasar. Pendidikan bermetamorfosa menjadi pelatihan yang meninggalkan nilai-nilai kewargaan (citizenship) menuju ke nilai pemilik modal.

Lima buah prinsip governansi korporasi (corporate governance), yaitu transparansi, akuntabilitas, responsibilitas, independensi, dan keadilan direduksi maknanya sampai ke tataran pamrih finansial sempit para penyelenggara korporasi. Prinsip transparansi memang dikaji, namun implementasinya ditujukan sebagai upaya pengurangan biaya modal perusahaan. Prinsip akuntabilitas memang dijadikan materi ajar, tetapi didominasi dan dikontekstualkan dengan profitabilitas korporasi.

Pertanggungjawaban (responsibility) dipasung dalam wacana penggunaan modal yang efisien. Independensi tampil sebagai upaya managemen korporasi untuk memperoleh penghargaan pasar yang lebih tinggi dalam wujud keuntungan finansial. Keadilan (fairness) ditunjukkan dengan beragam contoh keberhasilan pasar memberikan insentif kepada mereka yang beruntung mempunyai kapital dan sumber daya besar.

Ilmu pengetahuan dipandang sebagai bentuk investasi dalam model korporasi. Namun modal tersebut tidak menghasilkan kembalian (return) dalam bentuk pertanggungjawaban sosial, keadilan, dan wawasan sebagai insan cendekia. Dalam banyak kesempatan, pendekatan akuntansi biaya yang mengedepankan efisiensi dan kalkulasi manfaat-biaya dengan skopa yang sempit dalam skala yang masif telah mendangkalkan makna pendidikan. Tidak mengherankan kalau di seputar kita kemudian bermunculan fenomena yang mencerminkan sinyalemen di atas, seperti: aneka iklan pendidikan tinggi yang memberikan jaminan pekerjaan setelah lulus, pelacuran akademik untuk tujuan pragmatis non etis, dan krisis legitimasi pendidikan tinggi.

Segala peristiwa yang memprihatinkan dan memalukan dalam bidang keuangan selama beberapa dasawarsa terakhir membuka mata kita akan pentingnya tata kelola dan governansi yang baik pada bidang ini. Kasus kesalahan prosedur hingga penggelapan yang merupakan kejahatan kerah putih kelas tinggi telah mengakibatkan biaya sosial yang amat tinggi. Sementara itu, sistem hukum yang ada lebih bersikap lunak terhadap jenis kejahatan tersebut dibandingkan dengan perlakuan terhadap pelaku kejahatan kelas jalanan. Lebih parah lagi, sistem politik yang berlaku semakin memberikan jalan pada perilaku korup pada semua sendi institusi, baik eksekutif, legislatif, yudikatif, hingga korporasi. 
Penyalahgunaan wewenang untuk memperkaya diri dengan biaya yang ditanggung oleh masyarakat luas tidak dilakukan oleh sedikit orang. Penyakit ini sudah mewabah dan bersifat sistemik pada hampir segala aspek kehidupan kita. Perilaku korup bukan lagi cerminan busuknya beberapa buah pada satu pohon, melainkan sudah mengindikasikan rusaknya seluruh pohon yang ada pada suatu kebun. Penanganan yang harus dilakukan, dengan demikian, bukan lagi hanya dengan pemberian hukuman pada sejumlah pelaku, melainkan pencarian sebab musabab utama dan menyelesaikannya secara tuntas.

Terdapat paling tidak dua perspektif sikap yang dimiliki oleh masyarakat terhadap fenomena di atas. Pertama, dan yang paling populer, adalah sikap mengutuk keras dan menuntut penjatuhan hukuman yang setimpal bagi para pelakunya. Serentetan skandal keuangan yang telah terjadi dianalisis untuk tujuan penghakiman dan pembalasan. Harapannya, dengan hukuman yang berat, efek jera yang ditimbulkan dapat mencegah calon pelaku berikutnya dari kesalahan yang sama.

Kedua, sejumlah skandal keuangan tersebut dipandang sebagai sebuah bentuk penyadaran. Dengan berasumsi bahwa dunia bisnis sekarang masih terbuai oleh permasalahan rendahnya integritas dan belum kentalnya budaya transparansi dan akuntabilitas, maka skandal keuangan adalah alarm yang cukup efektif untuk membangunkan masyarakat dari ketidaksadarannya.

Sudah jamak fenomena korupsi dan skandal keuangan korporasi dibahas di ruang-ruang kelas perguruan tinggi. Analisis, kajian, dan kemudian sintesis dan rekomendasi bertaburan dari institusi pendidikan yang mengedepankan pendekatan ilmiah yang, seringkali, bebas nilai. Gioia (2002) mensinyalir adanya ambivalensi peran akademisi dalam upaya memerangi perilaku korup. Dia menyatakan bahwa banyak akademisi memandang diri mereka hanya sebagai pengamat fenomena korupsi dan penyelewengan finansial. Sebagai pengamat, para akademisi akan membatasi ruang gerak mereka dalam upaya praktis pemberantasan korupsi. Jika upaya praktis saja sudah terbatasi, maka ekspektasi terhadap adanya upaya ideologis hanyalah impian semata.

Lebih jauh, Gioia menekankan adanya peningkatan peranan perguruan tinggi bisnis dalam 'perang suci' ini. Dia merekomendasikan pengajaran etika praktis yang inheren pada mata kuliah-mata kuliah wajib bidang akuntansi, keuangan, pemasaran, dan sebagainya. Komitmen individual adalah kunci sukses dalam upaya di atas. Gioia menyadari bahwa rekomendasinya tak akan mampu melawan keseluruhan perilaku korup dalam efektivitas yang sempurna. Kerjasama yang erat dengan bidang lain seperti hukum, media, politik, dan sebagainya adalah upaya yang bisa ditempuh.

Adler (2002) sependapat dengan Gioia dalam hal rekomendasi untuk memberikan pendekatan etis dalam kurikulum di sekolah bisnis. Menurutnya, pelajaran etika harus didesain ulang dan diperkuat untuk menyadarkan peserta didik akan rasa tanggung jawab sosial mereka. Namun, berbeda dengan Gioia, Adler menegaskan pentingnya pendekatan struktur sosial alih-alih komitmen individual dalam penegakan perilaku etis.

Pertanyaan yang kemudian mengemuka dalam merespon kedua rekomendasi di atas adalah: apakah suguhan kurikulum pada sekolah bisnis sudah mempunyai pilar yang kokoh secara ideologis dan diajarkan kepada peserta didik secara praktis? Dengan kalimat lain, apakah muatan mata kuliah dalam kurikulum bisnis sudah mampu memandu perilaku peserta didik sehingga ketika mereka lulus dan berperan sebagai pelaku bisnis nyata, mereka mempunyai cukup pengetahuan fundamental untuk berperilaku etis? 


\section{Perspektif Keperilakuan pada Edukasi Akuntansi}

Akuntansi adalah sebuah disiplin yang pragmatis. Artinya, bidang ini dibentuk dan dikembangkan dengan mengedepankan kriteria kemanfaatan dan aplikabilitas dalam dunia (bisnis) nyata. Berangkat dari kebutuhan akan informasi untuk pengambilan keputusan, akuntansi didesain untuk melayani kepentingan praktis para penggunanya. Pengembangan akuntansi kemudian diarahkan untuk peningkatan efisiensi dan efektivitas managerial dan, sebagai konsekuensinya, peningkatan kesejahteraan pelaku bisnis.

Rasional, objektif, dan logis adalah istilah-istilah yang lebih mempesona bagi kita, baik sebagai insan ilmiah ataupun awam, daripada antonimnya seperti emosional, subjektif, dan absurd. Ketiga kata pertama sering ditempatkan sebagai pujian bagi seseorang, sedangkan lawan katanya menempati posisi sebagai pencerminan sifat manusia yang cenderung lemah. Berpikir dan bertindak rasional menjadi patokan dasar dalam semua aspek, termasuk pembuatan keputusan dan kebijakan ekonomi dan bisnis. Ilmu ekonomi tradisional mengasumsikan bahwa manusia adalah makhluk rasional. Dalam pengambilan keputusan manusia diasumsikan mempunyai semua informasi yang relevan, berkemampuan mengolah semua informasi tersebut secara objektif, dan memiliki daya kognitif yang mampu menghindari semua bias dalam pengambilan keputusan (Ariely, 2009). Terlepas dari sahih tidaknya asumsi rasionalitas, kekuatan keyakinan terhadap asumsi tersebut telah merasuki lapangan akademik dan bisnis praktis (Ghoshal, 2005). Ekonomika mengisyaratkan bahwa kesalahan dalam pengambilan keputusan dapat diperbaiki secara cepat lewat mekanisma pasar. Dengan demikian, asumsi rasionalitas dapat diaplikasikan pada beragam keputusan, dari keputusan investasi hingga pemilihan produk, dari penentuan kebijakan edukasi hingga penanganan bencana.
Ghosal (2005) dalam artikelnya yang provokatif, "Bad Management Theories are Destroying Good Management," menyampaikan tantangan kepada para ahli managemen berkaitan dengan semakin menyempalnya praktik managemen dari kaidah-kaidah etika dan kesejahteraan sosial. Sumantra Ghoshal secara spesifik mengajukan keberatan atas landasan teori yang digunakan dalam pendidikan bisnis yang mendegradasi manusia ke level pesimistik. Serangkaian teori yang menjadi arus utama dalam pendidikan managemen adalah teori-teori yang bersumber dari ekonomika tradisional. Manusia diasumsikan bersifat rasional penuh dalam pengertian mengedepankan kepentingan sendiri (self-interested behavior) dengan tendensi maksimalisasi laba. Asumsi ini tidak hanya mengeliminasi aspek emosi, cinta, kasih sayang, dan empati, tetapi juga merendahkan kreativitas dan keadaban manusia. Implikasinya, manusia adalah makhluk yang tak dapat dipercaya dan tidak bisa diandalkan dalam proses penciptaan kesejahteraan sosial. Teori-teori managemen dan keperilakuan yang "buruk" kemudian bermunculan dengan basis asumsi di atas. Teori-teori tersebut menekankan pada pentingnya pengawasan dan pengendalian yang ketat terhadap manusia (dalam hal ini pekerja) dalam institusi bisnis. Apakah pemahaman dan adopsi terhadap teori-teori yang "buruk" tadi merugikan pendidikan akuntansi? Dari perspektif ilmu-ilmu sosial, jawabannya adalah "ya" dengan intonasi yang kuat. Pengembangan dan adopsi teori pada domain ilmu-ilmu pasti tidak akan berpengaruh pada fenomena yang diteorikan. Misalnya, ketika Copernicus berteori Heliosentris, di mana matahari adalah pusat tata surya, maka fenomena pergerakan benda-benda angkasa yang menjadi objek teori Copernicus tidak akan terpengaruh dengan teori tersebut. Demikian juga ketika Albert Einstein mengemukakan bahwa energi yang tercipta akan sekuat massa elemen dikalikan kuadrat 
kecepatan cahaya, teori Einstein tersebut tak akan mengubah kenyataan penciptaan energi yang sesungguhnya terjadi. Namun, kasus yang sama tidak terjadi pada ilmu-ilmu sosial. Ghoshal menyatakan bahwa teoriteori ilmu sosial mempunyai karakter swabukti atau self-fulfilling. Teori yang dikembangkan dan kemudian digunakan dalam menjelaskan fenomena sosial akan berperan besar mengubah fenomena tersebut menjadi seperti atau mendekati kondisi yang diteorikan. Fenomena sosial adalah fungsi dari perilaku manusia. Teori yang menjelaskan perilaku manusia besar kemungkinan akan mengakibatkan perubahan perilaku, sehingga fenomena sosial pun akan mengalami modifikasi.

$$
\text { Apabila kita mengamati }
$$

perkembangan pemikiran ekonomika yang ada, para pendukung ekonomika keperilakuan menawarkan sudut pandang yang berbeda. Ide sederhana dari bidang ini adalah bahwa manusia mempunyai aneka bias dalam berkeputusan dan berperilaku. Rasionalitas manusia terbatas pada kemampuan kognitifnya dalam memperoleh dan mengolah informasi. Dalam kenyataannya, tingkat rasionalitas yang dimiliki manusia berada pada tataran di bawah tingkat rasionalitas yang diasumsikan oleh ekonomika tradisional.

Ihwal yang sama berlaku untuk bidang akuntansi keperilakuan. Riset akuntansi keperilakuan selama puluhan tahun dikonsentrasikan untuk menemukan dan menguji pendekatan-pendekatan yang digunakan dalam penyelesaian permasalahan dalam dunia managemen dan bisnis. Kemanfaatan riset akuntansi keperilakuan, sebagai konsekuensi cirinya yang pragmatis, diuji dengan pertanyaan apakah riset tersebut mampu mempengaruhi praktik akuntansi. Para periset akuntansi mempublikasikan kajian ilmiah mereka dengan konteks manfaat praktis dalam pengambilan keputusan dan pembuatan kebijakan. Hampir semua tulisan ilmiah yang bersumber dari penelitian menyertakan ekspektasi kegunaan hasil riset dari sudut pandang rasional dunia nyata.

Ariely (2009, 2010) berargumen bahwa manusia melakukan kesalahankesalahan yang sama secara berulang-ulang. Perilaku tak rasional tersebut dapat diprediksi dan bersifat sistematis, bukan random dan unik. ${ }^{1}$ Lebih jauh, Ariely menyatakan bahwa ekonomika menjadi lebih masuk akal apabila ilmu ini mengakomodasi realita bagaimana manusia sesungguhnya berperilaku dan bukan hanya bagaimana manusia seharusnya berperilaku.

Tesis Ariely mengisyaratkan terbukanya kesempatan bagi pelaku maupun periset bisnis dan ekonomi untuk terus berupaya memperbaiki kesalahan dalam pengambilan keputusan dan penentuan kebijakan. Jika kemungkinan kesalahan dan bias tersebut diakomodasi dalam proses keputusan, maka para ahli dan pelaku dapat menentukan strategi, metoda, dan alat keputusan yang tepat sehingga kualitas keputusan yang dihasilkan akan meningkat dan kemudian berpotensi meningkatkan kesejahteraan manusia. Ariely juga mencatat bahwa banyak risiko bisnis dan ekonomi yang dapat dihindari jika ketergantungan terhadap ilmu ekonomi tradisional dalam penentuan kebijakan dikurangi dan digantikan dengan argumentasi komplementer yang bersumber dari bidang atau sudut pandang ilmu keperilakuan.

Pemikiran di atas mempunyai argumentasi dan hasil-hasil penelitian yang solid sebagai dasar pijakannya. Semestinya, jika kemudian kita bawa ke konteks pendidikan akuntansi (atau bisnis dalam pengertian yang lebih luas), kesejahteraan yang meningkat tajam sebagai akibat dari peningkatan kualitas keputusan dan

\footnotetext{
${ }^{1}$ Beberapa contoh klasik bias dan kesalahan dalam perilaku ekonomi diajukan oleh sejumlah ilmuwan, misalnya Amos Tversky dan Daniel Kahneman (1986). Serangkaian teori menjelaskan fenomena ini, misalnya teori prospek dan framing.
} 
kebijakan sudah dapat diakses dan dinikmati oleh pelaku bisnis dan masyarakat luas sebagai salah satu pemangku kepentingan bisnis. Namun kenyataannya, manfaat yang diperoleh masih relatif sangat kecil dibandingkan dengan ekspektasi awal.

$$
\text { Caplan (1989) memuji }
$$

perkembangan dan kontribusi riset akuntansi keperilakuan. Sebagai bidang yang relatif baru, khasanah teori dan metodologi terus mengalami perkembangan yang pesat. Pendekatan metodologis yang kontemporer misalnya ditunjukkan oleh Parsons (2007) yang mengkombinasikan eksperimen lapangan dengan laboratorium. Riset pun mencakup semua bidang dalam akuntansi: auditing (misalnya Bhattacharjee dkk, 2007), akuntansi keuangan (misalnya Maines dan McDaniel, 2000), akuntansi managemen (lihat Chang, Cheng, dan Trotman, 2008), sistem informasi (lihat Mauldin, 2003), hingga perpajakan (contohnya Boylan dan Sprinkle, 2001). Caplan menengarai bahwa riset akuntansi keperilakuan masih dalam proses pencarian model (atau model-model) yang baku dengan rerangka berpikir yang lebih kuat. Namun demikian, masih menurut Caplan, masalah utama yang dihadapi oleh domain akuntansi keperilakuan tidak berkaitan dengan peningkatan kualitas riset, melainkan apati atau ketidakpedulian para pihak (pelaku bisnis dan penentu kebijakan ekonomi dan bisnis) yang semestinya memperoleh keuntungan utama dari riset akuntansi keperilakuan.

\section{Akuntansi dan Ideologi Kemanusiaan: Trust and Empower}

Ilmuwan sosial berbeda dan harus berbeda dengan ilmuwan eksakta. Karena ilmuwan sosial mempunyai pengaruh terhadap perilaku manusia lewat teori yang mereka kembangkan, mereka mempunyai tanggung jawab sosial dan moral yang lebih besar daripada ilmuwan eksakta. Peran teori di dalam khasanah ilmu sosial bukan terbatas hanya pada penjelasan dan prediksi fenomena, namun juga penciptaan fenomena. Realitas kita ciptakan dan kemudian kita beri makna, bukan sekadar kita persepsi dan nilai. Pengangkatan teori ekonomika tradisional sebagai teori utama dalam bisnis akan berakibat perilaku para aktor bisnis akan menjadi seperti yang diteorikan. Teori yang bebas nilai dan tak bernuansa moral akan membentuk insan bisnis dengan kecenderungan yang jauh dari tatanan nilai dan moralitas pula.

Simaklah pendirian Milton Friedman yang luar biasa berikut ini (2002: 133, dalam Ghoshal, 2005: 79):

Few trends could so thoroughly undermine the very foundations of our free society as the acceptance by corporate officials of a social responsibility other than to make as much money for their stockholders as possible.

Tidak mengherankan jika kewajiban sosial korporasi dewasa ini memang ditujukan untuk peningkatan laba perusahaan dan nilai pemegang saham. Jiwa sosial dalam program-program kemanusiaan yang berasal dari dana sebagian keuntungan perusahaan dikerdilkan sehingga yang berlaku adalah aturan main transaksional ekonomi. Pendukung panji kapitalisme menolak tudingan di atas. Forbes dan Ames (2011: 31) menulis, "Democratic capitalism is moral precisely because it gives people the greatest latitude to meet their needs and desires by serving those of their fellow citizens. Through doing so, it generates broad-based prosperity." Sudut pandang yang diambil oleh Forbes dan Ames tidak memungkinkan mereka untuk melihat dari sisi yang lain, yaitu bahwa kebebasan memilih yang dimiliki oleh warga masyarakat dalam ekonomi ditentukan oleh kemampuan mereka mengakses sumber daya ekonomi yang terbatas. Kemampuan orang tentu tidak sama, sehingga moral yang dimaksud dalam pernyataan kedua penulis tersebut hanya berlaku bagi para pemilik modal dengan kekuatan yang memadai untuk memperoleh kesejahteraan. 
Pendidikan akuntansi dirancang dan dikembangkan sebagai bentuk pendidikan yang mengedepankan keterbukaan dan kebebasan berpikir yang mengkombinasikan ketrampilan intelektual dengan identitas profesional. PricewaterhouseCoopers (PwC, 2003) mengklasifikasi pendidikan akuntansi menjadi tiga tataran dengan analogi dunia penerbangan. Tataran terendah adalah pendidikan yang membentuk insan dengan keahlian teknis seperti halnya seorang mekanik pesawat. Hasil pendidikan dengan level ini adalah seorang akuntan dengan kemampuan melaksanakan pekerjaan sesuai dengan prosedur operasional standar. Kedisiplinan menaati prosedur dan aturan main sampai ke hal yang paling kecil merupakan penekanan utama klasifikasi ini. Tingkatan berikutnya adalah pendidikan yang menghasilkan individu dengan kemampuan menyelesaikan masalah secara analitis seperti halnya seorang pilot. Kemampuan kognitif yang lebih tinggi diperoleh dari pendidikan bertaraf kedua ini. Akuntan yang dihasilkan akan menjadi pemikir yang mampu, selain belajar dan mengaplikasi prosedur operasional standar, mengambil keputusan berdasarkan pemikiran kritis akan problematika akuntansi dan keuangan. Tataran pemuncak adalah pendidikan yang mampu menghasilkan individu penyedia solusi kreatif yang berkarakter kepemimpinan. Tidak hanya kemampuan kognitif yang dibentuk di sini, melainkan juga ketrampilan mengelola emosi dan kreativitas. Astronot adalah analogi yang digunakan untuk akuntan yang merupakan hasil pendidikan pada level ini. Artinya, seperti halnya astronot yang menjelajah ke wilayah yang belum pernah terjamah siapa pun sebelumnya, akuntan yang dihasilkan oleh tipe pendidikan seperti ini adalah mereka yang mempunyai ketrampilan pengambilan keputusan kreatif dengan beragam sudut pandang dan pendekatan. Kebaruan dan keunikan adalah produk utama dari insan pada tataran ini.
PwC (2003) berpendapat bahwa untuk meningkatkan kepercayaan publik, pendidikan akuntansi harus memiliki kurikulum yang berkualitas, mengajarkan integritas, dan mengedepankan transparansi dan akuntabilitas. Pendidikan tinggi, menurut Giroux (2010), mempunyai tanggung jawab tidak hanya dalam proses pencarian kebenaran tetapi juga dalam upaya membentuk manusia yang memiliki kepekaan akan akuntabilitas sosial dan tanggung jawab kewargaan. Akar utama pendidikan tinggi bukanlah komersial, seperti yang didiktekan oleh kekuatan pasar bebas, namun moral berlandaskan pada nilai-nilai publik. Kompas yang digunakan dalam mengatur dan menjalankan pendidikan tinggi adalah ideologi pendidikan yang mengakomodasi pemikiran terbuka dan kreatif, warga masyarakat yang aktif, dan kesadaran akan hak dan kewajiban publik bagi para pelakunya. Paradigma pasar bebas dengan korporatismenya justru melanggar aturan dasar kebebasan karena menciptakan pengaturan yang ketat dalam wacana ekonomi dan memperlakukan insan akademis sebagai pekerja yang harus diawasi dengan bentuk pengawasan melekat dari atas ke bawah.

Jika akuntansi berkiblat pada kemauan pasar dengan secara konsisten menerapkan teori ekonomika secara eksklusif sebagai landasan edukasinya, baik pada ranah riset, aplikasi praktis, maupun pengajarannya, maka terciptalah sikap mental pelaku bisnis yang mengacu pada keyakinan distrust and control (ketidakpercayaan dan pengendalian). Pendidikan akuntansi akan tetap menerapkan kurikulum yang bertolak dari anggapan dasar bahwa manusia adalah makhluk yang tak dapat dipercaya sehingga diperlukan beraneka sistem untuk memastikan kerugian institusi tidak terlalu besar.

Profesi akuntansi adalah bidang yang memerlukan kepercayaan besar. Pendidikan akuntansi pun semestinya didesain untuk menghasilkan kepercayaan bagi keluarannya. Kepercayaan tidak akan 
tercipta dari asumsi pesimistik tentang manusia. Alih-alih berkomitmen eksklusif terhadap kelemahan manusia, semestinya dunia pendidikan akuntansi juga memberikan kesempatan kepada teori yang menjelaskan perilaku manusia dari sudut pandang manusiawi yang lebih optimis. Beberapa teori yang layak mendapatkan tempat pada panggung pendidikan akuntansi, lebih spesifik lagi pada diskursus akuntansi keperilakuan,di antaranya adalah teori keabdian (stewardship theory, Davis, Schoorman, dan Donaldson, 1997) dan teori keadilan prosedural (Lind dan Tyler, 1988).

Mekanisma swabukti akan membuat insan produk pendidikan akuntansi memaknai bisnis dan kehidupan dari perspektif pengabdian, kehormatan, dan keadilan seperti diisyaratkan oleh beragam riset akuntansi keperilakuan berbasis teoriteori nontradisional (misalnya Chang dkk, 2008). Harapannya akan terjadi pergeseran paradigma dari ketidakpercayaan dan pengendalian menuju kepercayaan dan pemberdayaan (trust and empowerment). Paradigma terakhir membuka jalan pada bisnis yang lebih bermartabat kemanusiaan dan berkepribadian moral dan sosial.

\section{SIMPULAN}

Pendidikan akuntansi adalah sebuah jalan menuju kesejahteraan dan kemerdekaan sosial. Sudah sepantasnya seluruh elemen yang terlibat di sana bahu membahu dalam mempertahankan kebaikan jalan tersebut. Kebaikan tersebut dapat didefinisikan dengan pengertian yang dangkal seperti halnya kualitas dan relevansi kurikulum hingga pengertian yang lebih fundamental seperti nilai-nilai kemanusiaan yang komprehensif. Pendidik akuntansi dapat mempersembahkan proses edukasi yang lebih terbuka terhadap cara pandang optimis atas manusia dengan memberikan penekanan yang lebih pada konsep, aksi, dan riset yang mempromosi kepentingan umum. Dalam proses pendidikan seperti itu, peserta didik akuntansi diharapkan menjadi insan cendekia yang mengedepankan martabat kemanusiaan. Keberhasilan pasar dan mekanismanya bersumber pada pemahaman antarmanusia akan hak dan kewajiban masing-masing, bukan atas dasar saling curiga akan perilaku aktor lain seperti yang diimplikasi oleh teori ekonomika tradisional.

Tindakan perbaikan pendidikan akuntansi dengan cara yang lebih substantif seperti yang disampaikan oleh esai ini bukan hanya akan meningkatkan relevansi kurikulum akuntansi, tetapi juga menempatkan ilmu sosial sebagai tuan rumah pada ranahnya sendiri. Tidak akan terjadi subordinasi ilmu sosial terhadap ilmu pasti. Tidak akan ada lagi perasaan inferioritas ilmuwan sosial. Akuntansi, sebagai penghuni domain ilmu sosial akan membentuk standar sendiri yang diturunkan dari prinsip ilmu sosial yang berjiwa kemanusiaan yang beradab dan berkeadilan.

\section{DAFTAR PUSTAKA}

Adler, P. 2002. Corporate Scandals: It's Time for Reflection in Business Schools. Academy of Management Executive. 16 (3): 148-149.

Albrecht, W.S. dan R.J. Sack. 2000. Accounting Education: Charting the Course through a Perilous Future. Sarasota, FL: American Accounting Association.

Ariely, D. 2009. Predictably Irrational; The Hidden Forces that Shape Our Decisions. London: HarperCollinsPublishers.

2010. The Upside of
Irrationality; The Unexpected
Benefits of Defying Logic at Work
and at Home. London:
HarperCollinsPublishers.

Bhattacharjee, S., M.J. Maletta, dan K.K. Moreno. 2007. The Cascading of Contrast Effects on Auditors' Judgments in Multiple Client Audit Environments. The Accounting Review. 82 (5): 1097-1117. 
Boylan, S.J. dan Sprinkle. 2001. Experimental Evidence on the Relation between Tax Rates and Compliance: The Effect of Earned vs. Endowed Income. The Journal of the American Taxation Association. 23 (1): 75-90.

Bradshaw, D. dan S. London. 2005. Shredded Credibility? The MBA Industry May Be Facing A Shakeout. Financial Times. 29 April: 17.

Caplan, E.H. 1989. Behavioral Accounting: A Personal View. Behavioral Research inAccounting. 1: 109-123.

Chang, L., M. Cheng, dan K.T. Trotman. 2008. The Effect of Framing and Negotiation Partner's Objective on Judgments About Negotiated Transfer Prices. Accounting, Organizations and Society. 33: 704717.

Cohen, J.R. dan L.L. Holder-Webb. 2006. Rethinking the Influence of Agency Theory in the Accounting Academy. Issues in Accounting Education. 21 (1): $17-30$.

Davis, J. H., F. D. Schoorman, L. Donaldson (1997). Toward A Stewardship Theory of

Management. Academy of Management Review 22 (1): 20-47.

Forbes, S. dan E. Ames. 2011. How Capitalism Will Save Us; Why Free People and Free Markets Are the Best Answer in Today's Economy. New York: Crown Publishing Group.

Friedman, M. 2002. Capitalism and Freedom $40^{\text {th }}$ Anniversary Edition. Chicago: The University of Chicago Press.

Ghoshal, S. 2005. Bad Management Theories Are Destroying Good Management Practices. Academy of Management Learning \& Education. 4 (1): 75-91.
Gioia, D.A. 2002. Business Education's Role in the Crisis of Corporate Confidence. Academy of Management Executive. 16 (3): 142144.

Giroux, H.A. 2010. The Disappearing Intellectual in the Age of Economic Darwinism. Global Research. 2002. The Corporate War Against Higher Education. Workplace.

Grossman, S.D. dan R.H. Strawser. 1978. Accounting and Behavioral Concepts: A Classroom Approach. The Accounting Review. LIII (2): 495-500.

Lind, E.A. dan T.R. Tyler. 1988. The Social Psychology of Procedural Justice. New York: Plenum Press.

Maines, L.A. dan L.S. McDaniel. 2000. Effects of Comprehensive-Income Characteristics on Nonprofessional Investors' Judgments: The Role of Financial-Statement Presentation Format. The Accounting Review. 75 (2): 179-207.

Mauldin, E.G. 2003. An Experimental Examination of Information Technology and Compensation Structure Complementarities in an Expert System Context. Journal of Information Systems. 17 (1): 19-41.

Merino, B.D. 2006. Financial Scandals: Another Clarion Call for Educational Reform - A Historical Perspective. Issues in Accounting Education. 21 (4): 363-381.

Monsour, E. 2007. Teaching Ethics to Accounting Majors. The Tax Adviser. May: 294-296.

Parsons, L.M. 2007. The Impact of Financial Information and Voluntary Disclosures on Contributions to NotFor-Profit Organizations. Behavioral Research in Accounting. 19: 179196. 
PricewaterhouseCoopers (PwC). 2003. Educating for Public Trust: The PricewaterhouseCoopers Position on Accounting Education. New York, N.Y.: PricewaterhouseCoopers.

Rynes, S.L., C.Q. Trank, A.M. Lawson, dan R. Ilies. 2003. Behavioral Coursework in Business Education: Growing Evidence of Legitimacy Crisis. Academy of Management Learning and Education. 2 (3): 269283.
Titard, P.L., R.L. Braun, dan M.J. Meyer. 2004. Accounting Education: Response to Corporate Scandals. Journal of Accountancy. November: 59-65.

Tversky, A. dan D. Kahneman. 1986. Rational Choice and The Framing of Decisions. The Journal of Business. 59

(4):

S251-S278. 